\title{
Thirty Years of Research on Children's Rights in the Context of Migration
}

\section{Towards Increased Visibility and Recognition of Some Children, But Not All?}

\author{
Ruth Brittle \\ Nottingham Law School, Nottingham Trent University, Nottingham, UK \\ ruth.brittle@ntu.ac.uk \\ Ellen Desmet \\ Migration Law Research Group/Human Rights Centre/cessmir, \\ Ghent University, Gent, Belgium \\ ellen.desmet@ugent.be
}

\begin{abstract}
This article presents a tentative analysis of 30 years of academic research in the field of children's rights and migration (1989-2019). Much research has addressed the plight of unaccompanied, refugee and asylum-seeking children, trying better to link children's rights considerations with international refugee law. Many publications address the best interests of the child principle and the right to be heard. Most research focuses on (migration towards) Europe. This has led to an increased visibility and recognition of children's rights in the context of migration.

However, there are still various blind spots in the research reviewed. Most research focuses on some children, but not all (e.g., accompanied children), on some rights, but not all (e.g., economic, social and cultural rights), and on some types of migration, but not all (e.g., economic migration). Moreover, refugee and migrant children tend to be studied as a group, which risks reducing attention for their internal diversity.
\end{abstract}

\section{Keywords}

migration - literature review - children's rights 
Migration is the field par excellence where children's rights come face to face with the sovereignty of states, in particular their prerogative to decide on the entry, residence and expulsion of non-nationals. This article presents a tentative analysis of 30 years of research in the field of children's rights and migration (1989-2019). ${ }^{1}$

During the past three decades, research on children's rights in the context of migration has increased considerably. Much research has addressed the plight of unaccompanied, refugee and asylum-seeking children, trying better to link children's rights considerations with international refugee law. Many publications address the best interests of the child principle and the right to be heard. Most research focuses on (migration towards) Europe. This has led to an increased visibility and recognition of children's rights in the context of migration.

However, there are still various blind spots in the research reviewed. Most research focuses on some children, but not all (e.g., accompanied children), on some rights, but not all (e.g., economic, social and cultural rights), and on some types of migration, but not all (e.g., economic migration). Moreover, refugee and migrant children tend to be studied as a group, which risks reducing attention for their internal diversity.

The conclusions presented in this paper draw on a review of scientific publications in English on children's rights in the context of migration. ${ }^{2}$ This methodological choice does not include reports from international and nongovernmental organisations and think tanks as well as publications in other languages. The review thus does not comprise all relevant research, but is limited to academic publications in English. Concretely, a systematic search of key international journals in the fields of children's (rights) studies, asylum and migration ${ }^{3}$ was carried out. This search was complemented with snowball

1 The authors wish to thank Sofia Sideridou for her research assistance.

2 Book reviews and general books with a few pages on the rights of refugee and/or migrant children were left out. Not all publications could be explicitly referenced in the article; the whole list can be consulted in the bibliography. The work of the UNHCR is referenced in their capacity as "norm-producing actor", thus to the extent that it concerns "guidelines".

3 Childhood; European Journal of Migration and Law; International Journal of Refugee Law; International Migration; International Migration Review;Journal of Refugee Studies; Refugee Survey Quarterly; The International Journal of Children's Rights. The main search terms were 'child*' and 'right"', with * indicating wildcard. Domestic migration journals were excluded from the systematic search, given that the restriction to English-language publications already favoured research on English-language jurisdictions. 
sampling. ${ }^{4}$ A children's rights perspective had to be central and explicit in the publication: a superficial reference to the Convention on the Rights of the Child (CRC) or an analysis of agency or resilience without an explicit link to children's rights did not suffice to be included.

As to disciplinary orientation, the analysis shows that the studies reviewed are for a large part undertaken from a legal perspective. This domination of legal approaches can probably at least partly be explained because an explicit link with "children's rights" was a criterion of selection. In addition, a substantial number of publications are grounded in the social sciences. Edited volumes often adopt at least a multidisciplinary approach, incorporating chapters from various disciplinary perspectives, such as law, sociology, anthropology and social work. Interdisciplinary interaction is mostly confined to the social sciences and humanities, though, with less engagement of, for instance, geography and the medical sciences (whereas the latter is very relevant for issues on age assessment as well as credibility assessment (memory and trauma) in refugee status determination).

A major part of the reviewed research on children's rights and migration concerns (migration towards) Europe. To a lesser extent, publications also relate to North America (US/Canada) and Australia, some of which adopt a comparative approach. Overall, there is a lack of published research on Africa (but see, e.g., Kaime, 2004; Tolfree, 2004), Asia (but see, e.g., Suleiman AlMakhamreh and Hutchinson, 2018; O'Donnell, 1994; Samuels, 1997), Latin America (but see, e.g., Holguín and Kapur, 2018; Goldberg 2018). Within Europe, most country-specific studies address Scandinavia and Western Europa, in particular Sweden, followed by the United Kingdom, Ireland, the Netherlands, Belgium, Norway and Denmark.

The predominance of legal studies in the reviewed publications is also reflected in the methodological approaches, in which doctrinal analysis and case law analysis feature prominently. Qualitative research has mainly taken the form of interviews with experts and/or children and young people themselves. More rarely, other methodologies are used, such as ethnography (but see, e.g., Smith, 2018; Giannopoulou and Gill, 2019) or "collective workshops of awareness and talking", which were combined with observation and individual interviews (Bailleul, 2018). Surveys or other quantitative methods are seldom employed in the research on children's rights and migration reviewed (but see, e.g., the reference in Candappa, 200o).

4 Given that both authors are Europe-based, this has probably led to a larger inclusion of Europe-based scholarship. 
After a chronological review of the main research themes identified over the past three decades, the paper highlights some specific research findings relating to the general principles of the CRC and reflects on how children and children's rights have been conceptualised in the literature reviewed. To conclude, the article identifies some directions for future research.

\section{$2 \quad$ Research Themes}

The literature reviewed implicitly interprets migration as "international migration", which implies crossing a state border. This leaves the situation of internal migration in general (but see, e.g., Chen et al., 2016; Desmet, 2018) and internally displaced children in particular largely under the radar (but see, e.g., Nunes, 2016). This is probably also a consequence of the fact that guidelines, for instance of the UN Committee on the Rights of the Child (CRC Committee), focus on international migration - even though the Committee has recognised that many of these guidelines are also relevant for children in a context of internal migration (UN Committee on the Rights of the Child, 2005: para. 5).

The publications reviewed paid considerably more attention to the plight of asylum seeking and refugee children than to children in other situations of migration, such as economic migration. Children suffering persecution and the consequences of conflict has been a matter of international concern since Eglantyne Jebb, in 1920, declared that 'the world's children stand in urgent need of better protection. ${ }^{5}$ Although the Fourth Geneva Convention of $1949^{6}$ and the Additional Protocol of $1977^{7}$ dealt with the treatment of children affected by armed conflict, the rights of refugee and asylum-seeking children were not separately recognised in an international instrument until the adoption of the CRC in 1989. The CRC guaranteed the child's "individual personality" rights and set the minimum rights which states should recognise for children (Price-Cohen, 1991). Article $22 \mathrm{CRC}$ recognises that refugee and asylum-seeking children are entitled to 'appropriate protection and humanitarian assistance',

5 Eglantyne Jebb, quoted by Gillian Wilson, in "The White Flame" (1976) The World's Children 7.

6 Geneva Convention Relative to the Protection of Civilian Persons in Time of War (Fourth Geneva Convention) (12 August 1949) 75 UNTS 287 (entered into force 21 October 1950).

7 Protocol Additional to the Geneva Conventions of 12 August 1949, and relating to the Protection of Victims of International Armed Conflicts (Additional Protocol I)(8 June 1977), 1125 UNTS 3 (entered into force 7 December 1978) and Protocol Additional to the Geneva Conventions of 12 August 1949, and relating to the Protection of Victims of Non-International Armed Conflicts (Additional Protocol II )(8 June 1977) 1125 UNTs 609 (entered into force 7 December 1978). 
and the CRC minimises the significance of refugee status for a child, emphasising that refugee and asylum-seeking children should be treated the same as other children (Price-Cohen, 1991: 689). The review of literature reveals that despite the CRC specifically providing for refugee and asylum-seeking children in Article 22, there remains a problematic relationship between children's rights and international refugee law. Although children were included in the Convention Relating to the Status of Refugees 1951 (Refugee Convention), there is little recognition of their specific protection needs in the context of forced migration and the fact that they may seek protection alone (Bhabha and Young, 1999; Bhabha et al., 2007; Pobjoy, 2017).

\section{$2.1 \quad 1990-2000$}

Early literature focused on aligning children's rights with international refugee law in the search for durable solutions for unaccompanied refugee and asylum-seeking children (Goodwin-Gill, 1995). At this time there was increasing concern about children caught up in conflicts around the world and the protection of children fleeing conflict and persecution as a result (Cohn, 1991). The conflict in the former Yugoslavia highlighted international concerns about evacuation of children and what needs to be considered in accordance with their rights and best interests (Ressler, 1993). Recognising that what is meant by "protection" in refugee discourse is not always clear, Goodwin-Gill championed utilising the CRC to fill the gaps and to interpret the Refugee Convention from a child rights' perspective (Goodwin-Gill, 1995). The UNHCR continued to develop its policy and guidance on refugee children and after the CRC was adopted, it became the UNHCR's normative frame of reference, central to its child-specific approach to refugee protection (UNHCR, 1993). ${ }^{8}$ There were recommendations on how the UNHCR should use the norms of the CRC to interpret its obligations in refugee situations (Price-Cohen, 1991; O'Donnell, 1994).

During this decade family reunification emerged as a theme, reflecting the UNHCR's priorities for refugee children (Abram, 1995). With the increase of unaccompanied and separated children arriving at the borders of EU states in particular, the literature, in turn, focused on how to address the protection needs of this particularly vulnerable group. Pask (1989), writing before the CRC was adopted, observed the lack of international standards for the treatment of unaccompanied refugee and displaced children, whereas Goodwin-Gill (1995)

8 See also UNhCr Refugee Children: Guidelines on Protection and Care (UNHCR, Geneva 1994); UN HCR Guidelines on Policies and Procedures in dealing with Unaccompanied Children Seeking Asylum (UNHCR, Geneva, February 1997). 
argued for the role of international law in securing durable solutions for unaccompanied refugee children, observing that '[s]olutions for children ... cannot be mortgaged to some future time and place, but to be durable must contribute now to the full development of the child'. Steinbock (1996) considered the "vexed" question of whether children, in their best interests, should remain in foster families in the host country or be restored to their ethnic, linguistic, religious and cultural refugee community. Russell (1999) studied the impact of the UK's Reservation to the CRC on unaccompanied refugee children in the UK. Through a review of UK caselaw he demonstrated that unaccompanied refugee children were not afforded the same protection and rights as other children in the UK. Ferenci (2000) discussed the implementation of international standards for unaccompanied refugee children and the practice and problems of asylum procedure in Austria.

There was little published research in the journals we looked at during this decade on the experiences of children in a migration context outside of Europe; a Euro-centric approach was thus dominant. In a rare example, Samuels examined the impact of Hong Kong's immigration law on children and families, illustrating the tension between children's rights and best interests and the state's right to control entry to its territory (Samuels, 1997). In addition to the legal approaches, there was also literature from other disciplines, for example how social scientists should carry out research and formulate policy in relation to refugee children utilising the framework of the CRC (McCallin, 1991; McCallin, 1992). As states began to acknowledge the need to incorporate a child-centered approach into immigration and asylum law, commentary on policy and guidelines helped to clarify states' obligations (e.g., on the US Guidelines for Children's Asylum Claims: Bhabha and Young, 1999). Candappa (2000) examined the interaction between refugee children and their social and economic rights in the UK.

\section{$2.2 \quad 2001-2010$}

The problematic relationship between the children's rights, as articulated in the CRC, and states' interpretation of the Refugee Convention, was discussed during the UNHCR's Global Consultations in 2001 (50th anniversary of the Refugee Convention)..$^{9}$ In the Global Consultations on refugee children, the UNHCR recognised its own shortcomings in relation to the protection of refugee children, acknowledging that, in practice, refugee children 'are often

9 The Global Consultations took place between 2001 and 2002 and are collated in E. Feller, V. Turk and F. Nicolson, Refugee Protection in International Law: UNHCR's Global Consultations on International Protection (Cambridge University Press, 2003, reprinted in 2005). 
overlooked and considered "on-the-sidelines" of core protection and assistance work' (UNHCR, 2002). The protection needs of children were also discussed in the context of family reunification and aligned the CRC provisions on nonseparation, reunification and right to respect for family life with equivalent rights in the Refugee Convention and international human rights law (Jastram and Newland, 2005). The UNHCR advocated a "mainstreaming" of children's rights approach in all protection and assistance activities for refugee children and contributed to the framing of research on refugee children as well as other children of concern to the UNHCR, for example victims of sexual exploitation, children affected by conflict and children separated because of migration (UNHCR, 2002).

In 2005, the CRC Committee published its General Comment No. 6 on the treatment of unaccompanied and separated children outside their country of origin (UN Committee on the Rights of the Child, 2005). McAdam, who aligned her important work on complementary protection with children's rights, argued that the CRC, especially the best interests principle, should be a source of protection for a child who does not qualify for refugee status (McAdam, 2006). Bhabha et al. carried out significant and detailed empirical research into the experiences of unaccompanied children seeking asylum in Australia, the UK and USA, which highlighted that states tended to interpret the Refugee Convention through an 'adult-focused lens' with little recognition of the need for a child-centred approach at all stages of the asylum process (Bhabha, Crock, Finch and Schmidt, 2007).

The UNHCR published guidelines on determination of the best interests of the child for field staff in 2008 (UNHCR, 2008), followed in 2009 by updated guidelines on handling claims by child asylum-seekers (UNHCR, 2009). The UNHCR observed that in the past, an adult-centric interpretation of the Refugee Convention meant claims by refugee children were often 'assessed incorrectly or overlooked altogether' (UNHCR, 2009). The UNHCR's focus on aligning children's rights and international refugee law and their mainstreaming of children's issues into protection and assistance activities, was accompanied by a significant increase in research literature on refugee children's rights. In particular, there were a number of articles on the protection of unaccompanied children (Halvorsen, 2005; Martin and Curran, 2007), gaps in protection for children in mixed migration flows (MacDonald, 2008; Feijen, 2008), the rights of trafficked children to be recognised as refugees (e.g. in Canada: Grover, 2006) and the obstacles to migrant children's rights' enforcements (Bhabha, 2009). Within (legal) migration research, family reunification became a more prominent topic, with a growing emphasis on the European Court of Human Rights' developing approach to children's rights in the context of Article 8 of 
the European Convention on Human Rights (ECHR) (Spijkerboer, 2009; Van Walsum, 2002, 2009).

\section{$2.3 \quad 2010-2019$}

In 2012, the CRC Committee held a Day of General Discussion on the rights of all children in the context of international migration. In the same year, the UNHCR published its Framework for the Protection of Children, which demonstrated its 'renewed commitment to the protection of children ... to ensur[e] a better future for children, their families and communities' (UNHCR, 2012: 7). In 2014, the Inter-American Court of Human Rights (2014) issued an Advisory Opinion on the "rights and guarantees of children in the context of migration and/or in need of international protection". In 2017, the UN Committee on the Protection of Migrant Workers (CMW) and the CRC Committee (2017a, 2017b) adopted two General Comments on the human rights of children in the context of international migration, elaborating on the general principles and state obligations respectively. At the end of 2018, the UNHCR updated its guidance on assessing and determining the best interests of the child to reflect changes and developments in policy and practice (UNHCR, 2018). The changes laid out in the updated guidance were based on the experiences of the UNHCR's field workers implementing the previous best interests guidance (UNHCR, 2008) and building on the practice in national child protection systems. However, the Guidelines also reflected and were influenced by other research into the experiences of refugee and asylum-seeking children and the UNHCR's work with other international organisations (e.g., UNICEF-UNHCR, 2014). In December 2018, the UN General Assembly adopted the Global Compact on Refugees and the Global Compact for Migration (2018a; 2018b). Although not focused on children, the commitment to international cooperation and shared responsibility on refugee protection and to ensuring safe, orderly and regular migration includes recognition of children's rights in these contexts.

From 2010 onwards, there has been a significant increase in literature on child refugee and asylum-seekers, revealing diverse theoretical and methodological approaches to research on children seeking international protection, emerging themes and increased attention for migrant children more generally. The last two years have witnessed a rise of edited volumes on children, their rights and migration (e.g., Bhabha et al, 2018; Crock \& Benson, 2018; Sedmak et al., 2018).

A particular research stream continues to explore how a children's rights perspective could and should impact on the development of international and/or European refugee law, either in general (e.g., Arnold, 2018a; Pobjoy 2015; Pobjoy, 2017; Smyth, 2014; Thorburn Stern, 2015), with a focus on protecting 
children fleeing armed conflict (e.g., Tyler and Whitman, 2018) or in specific country-contexts (e.g., Schoenholz 2012 and Frydman and Bookey, 2018 on the US). More recently, research has also focused specifically on appellate asylum proceedings (Arnold 2018b; Joseffson 2017). Pobjoy's (2017) comprehensive analysis of over 2,500 cases heard in the ECtHR and in the common law jurisdictions of Australia, Canada, New Zealand, the UK and the USA provides a significant contribution to the discourse on using the CRC effectively in asylum proceedings to ensure the child's rights in the process are protected. Pobjoy's analysis supports his argument that there are three modes of interaction (procedural guarantee, interpretative aid and independent source of protection) where the CRC may be engaged to assist in determining the status of an at-risk child (Pobjoy, 2017: 6-7).

A very significant share of research in this decade has been devoted to unaccompanied (and separated) minors, building on the trend from previous decades. These publications address a variety of topics, such as the best interests principle (e.g. Sedmak et al., 2018), age assessment (e.g., Kenny and Loughry, 2018), ${ }^{10}$ guardianship (e.g., Arnold et al., 2014; Hedlund and Salmonsson, 2018), experiences and perceptions of unaccompanied minors in the asylum and reception system (e.g., Connolly, 2015; Kaukko, 2017; Shamseldin, 2012), and trafficking of unaccompanied minors (e.g., Lelliott, 2017). Various publications concern case studies of the legal and actual protection of unaccompanied children in specific countries. ${ }^{11}$ By contrast, there is little research specifically on accompanied minors (but see, e.g., Arnold, 2018b; Liden and Rusten, 2007; Lundberg and Lind, 2017; Pobjoy 2017). This lack of research on accompanied minors risks obscuring the rights and interests of children and young people who migrate with their parents or someone with parental authority, as well as the specific challenges they are facing, in a forced migration situation, during refugee status determination or in more stable forms of migration, such as in the context of free movement agreements and labour migration. This dearth of research on children when they are not "alone" reflects the fact that children are rendered invisible in migration processes and that their distinct experiences and interests are ignored (Bhabha, 2014).

Family reunification remains a key theme, especially in the European Journal of Migration and Law (Klaassen and Rodrigues, 2017; Smyth, 2015). Other

10 A number of the studies on unaccompanied minors discuss the challenges surrounding age assessment as a subtopic.

11 E.g., on Austria (Dursun and Sauer, 2018), Australia (Everhuis, 2013), Canada (Sadoway, 2018); France (Bailleul, 2018), Greece (Giannopoulou and Gill, 2019), Ireland (Mullally, 2011), Italy (Rozzi, 2018), Slovenia (Sedmak et al., 2018), South Africa (Anderson et al., 2017), Sweden (Lundberg, 2018), and the United Kingdom (Wilding, 2017). 
topics seem to have received less scholarly attention, such as the plight of undocumented child migrants, notwithstanding their often very precarious situation (but see Andersson, 2012; de Clerck et al., 2011; and indirectly Sullivan, 2014, on conditional residence for unauthorised immigrant parents). A limited number of publications have looked into migration and social and economic rights in general (e.g., Lundberg and Dahlquist, 2012), or specific rights such as the right to education (de Clerck et al., 2011) and the right to health care (Andersson, 2012). Until recently, the publications reviewed engaged relatively little with the interference with the right to liberty caused by immigration detention (but see Smyth, 2013), yet this seems to be changing (e.g., Ghezelbash, 2018; Muntarbhorn, 2018; Neuman, 2018; Triggs, 2018; Smyth 2019). This may be explained by the tendency of states increasingly to resort to immigration detention, including of families with children, on the one hand, and the largescale civil society mobilisation to end child immigration detention, on the other. ${ }^{12}$ The issue of deportation has not been extensively dealt with either (but see Smyth 2015; Langrognet, 2018).

Drywood (2011) has researched the potential of "mainstreaming" children's rights in EU asylum and migration law, adequately to respect the rights of children and young people. Farmer (2018:174) has argued that the advancement of and focus on the child protection framework at the expense of the overall migrant rights framework has led to an unbalanced system which cannot completely fulfil children's needs. Therefore, she argues,

the best way for advocates to secure migrant children's rights is to deepen their engagement with the broader advocate movement for a revised global migration framework while also retaining children's rights instruments at the core of their work (ibid.).

This position from an advocacy perspective can be linked to calls in general children's rights studies continuously to reflect on the institutionalised distinction between children and adults and consider rights of children and adults more firmly as inextricably intertwined (Desmet et al., 2015).

\section{Research on the CRC General Principles in the Context of Migration}

It is not possible, within the scope of this article, to review all of the research on refugee and migrant children right by right. In our review of the literature,

See, e.g., https://endchilddetention.org/. 
we found examples of research which examined the impact of the CRC as a whole on children's claims for asylum. For example, Goodwin-Gill $(1995,2012)$ calls for a 'total realignment of protection away from the formalities of 1951-style refugee status determination towards a complete welfare approach' based on the rights of the child in the CRC. Connolly (2015) interviewed 29 young asylum seekers in the UK and asked them if they felt that the CRC had or had not been part of their asylum and resettlement experiences. Pobjoy (2017: 186-238) argued that the CRC has the capacity to provide children with a complementary (and independent) source of protection, although the focus is primarily on Articles 3, 6 and 37, CRC.

As the four general principles highlighted by the CRC Committee are the rights most commonly reviewed, we chose to focus here on the research carried out in the context of these rights. In the literature reviewed, these four principles have not been examined comprehensively together in the context of immigration and refugee law. The focus is primarily on two of the general principles - the best interests of the child and the right to be heard. The CRC Committee (individually and jointly with the $\mathrm{CMW}$ ) has recognised the relevance of the four principles in the context of refugee, asylum-seeking and migrant children (UN Committee on the Rights of the Child, 2005; UN Committee on the Protection of Migrant Workers and UN Committee on the Rights of the Child, 2017a).

The best interests principle of Article 3(1), CRC features in most of the articles which discuss children's rights in the context of international migration and refugee law. Even before the CRC was adopted, the UNHCR identified best interests (alongside family reunification) as a guiding principle in all decisions concerning children (UNHCR ExCom, 1987). The UN Committee on the Rights of the Child (2013) stipulates that Article 3(1) operates as a threefold concept: as an interpretative legal principle, as a rule of procedure and as a substantive right (ibid, para 6). The best interests principle is relevant to children's claims for asylum and should be implemented throughout the asylum process and be a consideration as part of the treatment of refugee and asylum-seeking children (UN Committee on the Rights of the Child, 2005). The principle has an interpretative role in the context of the refugee definition and the meaning of child-specific persecution (Pobjoy, 2013; Pobjoy, 2017). Article 3(1) is a procedural guarantee both during the asylum process and after a decision has been made (whether positive or negative) (Pobjoy, 2013). The best interests of the child are relevant as a substantive issue in any case involving a child and ought to be considered as an independent source of protection (Pobjoy, 2015; Pobjoy, 2017). However, best interests does not mean that every child migrant should be granted entry and residence in a host country, return is sometimes in a child's best interests where it ensures a child's well-being and safety 
(Schoenholz, 2012). A child-rights based framework should be established for dealing with children's asylum claims, with a child's best interests at the heart of this framework (Pobjoy 2013; Pobjoy 2017).

One approach to safeguarding a child's best interests in asylum and immigration cases draws on a "science-based" model, which has been developed in the Netherlands as a framework for assessing and determining the best interests of the child (e.g., Beltman et al., 2016; Kalverboer et al., 2017; Van Os et al., 2018). The importance of guardians for unaccompanied and separated children in best interests decision-making has been highlighted by research in Belgium, Ireland and the Netherlands (Arnold, Goeman and Fournier, 2014). There is criticism of the fact that the European Court of Human Rights does not adopt a rights-based or principled approach to its use of the best interests principle in its jurisprudence (Smyth, 2015). Empirical research into the care and protection of unaccompanied asylum-seeking children identifies the indeterminacy of the best interests principle as a barrier to implementation of the CRC in England, Ireland and Sweden (Shamseldin, 2012). Much of the literature reviewed focused on best interests and children's experience of the asylum process, for example in Australia (Crock, 2008; Crock and Bhabha, 2006), Ireland, England and the Netherlands (Arnold, Goeman and Fournier, 2014), Sweden (Lundberg, 2011) and the UK (Bolton, 2012). The best interests principle has been mainstreamed into EU policies (Drywood, 2011) and into EU law, especially in Article 24(2) of the Charter of Fundamental Rights ${ }^{13}$ and in the regulations and directives which form the Common European Asylum System (CEAS), ${ }^{14}$ which aim gradually to harmonise asylum law and policy in EU member states (Smyth, 2014). However, there has not been enough guidance on the role of the principle under Article 24(2) of the Charter, especially in the context of family reunification (Klaassen and Rodrigues, 2017). Schoenholz's research identifies the emphasis on the best interests principle as a procedural tool, especially in Europe and North America, and stresses the importance of developing a toolbox for decision-makers to apply best interests substantively (Schoenholz, 2012).

The child's right to be heard and participate in migration and asylum processes as well as national implementation of the right were highlighted in the literature (Liden and Rusten, 2007; Ottosson and Lundberg, 2013). For example,

13 Charter of Fundamental Rights of the European Union (18 December 2000), 2000/C $364 / 01$ and (26 October 2012) 2012/C 326/02.

14 CEAS comprises the Dublin Regulation, the Qualification Directive, the Reception Conditions Directive, the Asylum Procedures Directive and the Eurodac Regulation. Also relevant are the Temporary Protection Directive, the Schengen Borders Code, the Family Reunification Directive and the Returns Directive. 
adherence to the child's right to be heard in Sweden is not rights-based in national law and has an impact on the treatment of best interests of the child in asylum decisions (Lundberg, 2011). Some of the literature focuses on participation as a due process guarantee (Pobjoy, 2013: 116-121; Crock, 2015: 237238). The obligation to hear and give due weight to the views, wishes and feelings of the child is part of the refugee status determination procedure and is increasingly recognised in domestic legislation, guidelines and judicial decisions (Pobjoy, 2017: 55-59). It is noted, however, that efforts to include children in decisions about their lives and empowering them to be active in the fulfilment of their rights is often tokenistic (Tolfree, 2004: 89). Children should be recognised as stakeholders in the choice of where they live and who they live with - children can be agents of child protection in refugee emergencies (Tolfree, 2004). Although hearing from the child is recognised as being important in asylum and immigration proceedings, ${ }^{15}$ there is little evidence that children are heard directly and that their views, wishes and feelings inform the decision-making process (Stalford, 2018). The reality of unaccompanied children's participatory experiences in immigration proceedings reveals that there are legal, practical and ethical barriers to giving effect to the child's right to be heard in such proceedings, especially when questions of "due weight" and credibility are assessed by the decision-maker (Stalford, 2018). Children's rights and interests are subsumed into the claims of the adults they are with (Ottosson and Lundberg, 2013) or children are invisible in the process and not heard (Pobjoy, 2017). A child's right to be heard in this context struggles to find a place in adversarial immigration proceedings (Liden and Rusten, 2007; Stalford, 2018).

Non-discrimination (under Article 2, CRC), in the context of asylum-seeking and migrant children, has had some attention in the literature and is acknowledged as a key principle in asylum matters (Smyth, 2014:32-33), as a normative framework for pursuing and protecting children's rights (Stalford, 2012: 50-55) and in the formulation of EU law and policy (Drywood, 2011). The lifting of the UK's reservation to the CRC in 2008 levelled the playing field between citizen and non-citizen children (Bolton, 2012: 235). Breen has examined how recent judicial decisions in Ireland sanction discrimination against children born to non-citizen parents to protect the integrity of the Irish asylum and immigration system (Breen, 2003). The lack of child-specific provisions for separated asylum-seeking children means that the Australian refugee status determination system indirectly discriminates against such children (Evenhuis, 2013).

$15 Z$ ZH(Tanzania) v. Secretary of State for the Home Department [2011] U KSC 4, para. 37. 
The right to life, survival and development in Article 6, CRC has received little attention in the literature on immigration and asylum. Smyth (2014) notes that it has two important applications in the asylum context - first, informing the assessment of whether a child has an international protection need and whether the child has reached the "well-founded fear" of persecution threshold; second, this right gives substance to the economic and social rights of the child in the context of asylum and migration (Smyth, 2014: $36-38$ ). Pobjoy (2017: 192-193) emphasises that the CRC Committee has linked Article 6, CRC to the non-refoulement obligation of states, which means that a state cannot return a child to the country of origin where there are 'substantial grounds for believing that there is a real risk of irreparable harm to the child' (UN Committee on the Rights of the Child, 2005: para. 28). Article 6, CRC significantly extends the non-refoulement obligation of states beyond the international human rights law conception of the right to life because Article 6(2) imposes a positive duty on states to fulfil to the maximum extent necessary the survival and development of the child (Pobjoy, 2017: 192-193). The non-refoulement obligation has been considered in the recent jurisprudence of the CRC Committee. ${ }^{16}$ Arnold (2018a), in her analysis of conceptualisation of children in the Refugee Convention, focuses on Article 6, CRC as 'the benchmark for children's rights' and argues that violations of children's rights to life, survival and development are central to the refugee question and a violation of the child's right to develop 'should carry significant weight in the analysis of a refugee claim' (ibid., p. 8). Beyond this, there is a gap in the literature on the right to life, survival and development in the context of migration and refugee law.

\section{Conceptualisations of Children and Children's Rights}

How are children and children's rights conceptualised in the publications reviewed? We make a distinction between whether authors clarify their own position on these concepts, on the one hand, and whether they investigate others' perceptions and understandings of children and/or children's rights, on the other.

To start, most authors do not indicate how they themselves conceptualise children. Moreover, "migrant/refugee children" are often considered and studied as a group, which may overlook internal heterogeneity. For instance, we did

16 UN Committee on the Rights of the Child, IAM (KYM) v. Denmark, UN Doc. CRC/ C/77/D/3/2016 (25 January 2018); UN Committee on the Rights of the Child, DD v. Spain, UN Doc. CRC/C/8o/D/4/2016 (12 February 2019). 
not identify academic publications which specifically look at the rights of migrant children with disabilities. ${ }^{17}$ Relatively few publications engage with other identity markers of refugee and migrant children from an intersectionality perspective, such as ethnicity, sexual orientation, gender identity and gender expression, beyond their impact on the refugee status determination procedure (e.g., Hedlund and Wimark, 2019). Age is mostly a topic in relation to age assessment (e.g., Prabhat, Singleton and Eyles, 2019), but research on migrant children does not often disaggregate further between specific groups (e.g., younger and older children) in the context of migration, notwithstanding their potentially different needs and experiences. This risks reducing children to their migratory experiences.

Some publications do investigate perceptions of children among policy and decision-makers or other research participants. As such, they point to the tensions caused by the fact that the children and young people concerned are both a "child" legally speaking and a "migrant"| "asylum seeker"/"refugee" (accompanied or unaccompanied) (e.g., Bhabha, 2001; Dursun and Sauer, 2018; Rozzi, 2018). In the Swedish asylum process, '[c]hildren in families seeking asylum are not adult enough ... for their asylum claims to be considered, and not children enough to deserve qualification as bearer of children's rights' (Lundberg and Lind, 2017). Ethnographic research on unaccompanied minors in reception centres in Greece showed that host communities and Greek officials perceived childhood as a universal and linear process, strongly connected to chronological age. Moreover, unaccompanied asylum seeking minors were perceived as dependent burdens for guardians or the state and/or as "undeserving" migrants. These perceptions and discourses impacted on how refugee children experienced the legal system (Giannopoulou and Gill, 2019).

Turning to children's rights, a few authors explain how they understand children's rights, before setting out their research findings. For instance, Lundberg (2018: 262) has adopted a performative approach to children's rights, conceiving rights as entitlements, and aims to understand 'how the present political situation affects when, where and how rights claims can be made by young people seeking protection in Sweden'. Gornik (2018) has emphasised the power relations which shape the implementation of the rights of unaccompanied minors. Most authors, however, do not conceptualise children's rights explicitly.

Moreover, few publications probe for understandings of children's rights among their research participants (but see, e.g., Connolly, 2015; Chen et al.,

17 This does not mean that the theme has not received any attention: see, for instance, UnICEF (2007), Promoting the Rights of Children With Disabilities, Innocenti Research Centre. 
2016; Desmet, 2018). They rather focus on experiences of children, for instance in the asylum system, but do not ask explicitly how these children or other stakeholders understand the rights of children in the context of migration (see in general the work on "living rights" by Hanson and Nieuwenhuys, 2013).

Overall, it is valid to observe that there is also a relative lack of theorisation in the field of children's rights research (Quennerstedt, 2013) in the context of migration. Many studies focus on the implementation of children's rights in concrete contexts, and thus on the "gap" between the law in the books and the law in action. In this regard, more emphasis seems to have been put on protection compared to autonomy, probably triggered by the vulnerable situation in which migrant children and young people often find themselves and the huge challenges as to the realisation of children's rights in migratory contexts. However, the protectionist approach of the children's rights framework, which constructs children mainly as vulnerable and in need of protection, may work against recognising their agency (Giannopoulou and Gill, 2019).

Few publications adopt a critical perspective on children's rights standards, investigating for instance when and whether children's rights (law) itself - as enshrined in the CRC and/or implemented at the domestic level - may have unintended or undesirable consequences. One example of the latter approach is Stalford (2018), who demonstrates that a child's participation in the asylum process in the UK, which purports to give effect to a child's right to be heard, may in fact undermine a child's claim for asylum and works against other rights of the child, especially the best interests principle. In addition, Prabhat et al. (2019) have challenged the age limit of 18 of the children's rights framework and plead for a smoother transition to adulthood for British migrant young people between 18 and 21 years, inspired by the UK's youth care system. A critical analysis of the impact on children's rights when a child transitions to adulthood has been the focus of research utilising the frames of best interests, durable solutions and belonging (Allsopp and Chase, 2019). Chase's (2019) longitudinal research, adopting the capability approach, focuses on the experiences of unaccompanied migrant children becoming adults, whilst their status is precarious. At a more conceptual level, Ryngaert and Vandenhole (2017) have suggested that the concept of nuanced vulnerability employed in children's rights law, could inspire general human rights law.

\section{Directions for Future Research}

Which directions for future research in the field of children's rights and migration emerge from this review? First, studies could take a more firmly 
interdisciplinary approach, also incorporating disciplinary perspectives which are quite absent from the review undertaken here, such as political sciences, medical sciences and geography. Second, even though recent edited volumes include more research relating to Africa, Asia and Latin America (e.g., Bhabha et al., 2018; Crock and Benson, 2018), some of the international journals could strive to publish more research on children's rights and migration that goes beyond the European and English-speaking nations (United States, Canada, Australia). Third, methodologically, there has been participatory and ethnographic research on children in the context of migration (for instance in the Journal of Refugee Studies and Childhood), but relatively few of these publications explicitly focus on children's rights, enquiring, for instance, how children conceive their rights and the implementation and realisation thereof. There is also more room for mixed methods research designs as well as for research methods that recognise the agency of children and young people, for instance by involving them as co-researchers in an (action) research on children's rights or combining participatory observation and participatory research (Evans, 2013).

From a theoretical perspective, authors could be more explicit as to how they conceptualise children and children's rights when undertaking research in the context of migration. In this respect, the diversity within the group of refugee and migrant children should be duly taken into account from an intersectionality perspective, in order to avoid the risk of "reducing" these children to their migratory experiences. Moreover, research could engage more deeply with childhood images underlying children's rights as well as migration laws and policies, and adopt a critical approach to children's rights.

Children's rights that appeared as under-researched from the sample reviewed include the right to life, survival and development, the right to privacy, and certain political rights such as the rights to freedom of expression, freedom of religion and freedom of assembly. Furthermore, the gap in research on the economic, social and cultural rights of migrant and refugee children including the right to play - needs to be addressed, especially in light of the emphasis on protecting these rights in the joint General Comments (UN Committee on the Protection of Migrant Workers and UN Committee on the Rights of the Child, 2017a and 2017b) and the jurisprudence of the ECtHR ${ }^{18}$ and the

18 See, e.g., ECtHR, Rahimi v. Greece Application No. 8687/08 (5 April 2011); ECtHR, Khan v. France Application No. 12267/16 (28 February 2019); ECtHR, Sh.D and others v. Greece, Austria, Croatia, Hungary, Macedonia, Serbia and Slovenia Application No 14165/16 (13 June 2019). Only the complaints against Greece were held to be admissible. 
European Committee of Social Rights. ${ }^{19}$ More attention could also be paid to the principle of non-discrimination and the right to liberty. Finally, little research has been carried out on aspects of integration in the host society as well as return to and reintegration in the country of origin.

Overall, research has been dominated by the focus on unaccompanied and asylum-seeking and refugee children. Particular groups of children that have received less research attention are accompanied children, children in mixed migration, children living in protracted refugee situations, children who do not have a legal right to stay in a country ("undocumented" children), internally migrant children and - especially - internally displaced children. Conspicuously absent from the review was the situation of children in the context of labour migration, children left behind in the country of origin (beyond their inclusion in research on family reunification), environmentally displaced children, and children who migrate between developing countries ("South-South migration", see Schoenholz (2012)). The Global Compacts (UN General Assembly 2018a; 2018b) contain aspirational goals both for safe, orderly and regular migration and the protection of the human rights of refugees, but there are gaps in protection which provide further need for research. There has been important work done in this context generating principles and recommendations which have had some impact across the UN system (Dotteridge and Bhabha 2017).

Moreover, there is much potential to assess current evolutions in the field of asylum and migration law and policy from a children's rights perspective. Examples include access to international protection and in particular the ever more creative ways states outsource/off-shore migration control in order to prevent people from arriving on their shores and triggering their obligations in relation to non-refoulement, the privatisation and the financing (e.g. through international development aid in the EU) of migration control, the securitisation of migration (cf. "crimmigration"), and the interoperability of EU border and security information systems.

Finally, research has found that migration policies often "trump" children's rights considerations (e.g., Bhabha, 2001; Breen, 2003; Smyth 2019; Thronson 2018a, 2018b; Zschirnt, 2011). This seems to be a world upside down, as children's and human rights should be the beacons that demarcate the room for manoeuvre states have when designing and implementing their migration policies. However, as Thronson (2018b: 167) argues, 'reducing the tension

19 See, e.g., ECSR, EUROCEF V. France, Decision on Merits, Complaint No. 114/2015 (24 January 2018). 
between [...] immigration law and conceptions of children's rights in international and other domestic contexts is possible'.

\section{References}

Abram, E. (1995), "The Child's Right to Family Unity in International Immigration Law", Law and Policy, 17, 397-439.

Allsopp, J. and Chase, E. (2019), "Best Interests, Durable Solutions and Belonging: Policy Discourses Shaping the Futures of Unaccompanied Migrant and Refugee Minors Coming of Age in Europe", Journal of Ethnic and Migration Studies. 45(2) 293-311.

Andersson, H. E. (2012), "International Conventions and the Regulation of Migration: The Convention on the Rights of the Child and Sweden", The International Journal of Children's Rights, 20(1), 122-140.

Anderson, K., Apland, K. and Yarrow, E. (2016), "Unaccompanied and Unprotected: The Systematic Vulnerability of Unaccompanied Migrant Children in South Africa" in Liefaard, T. and Sloth-Nielsen, J., The United Nations Convention on the Rights of the Child: Taking Stock after 25 Years and Looking Ahead (361-389). Leiden and Boston: Brill Nijhoff.

Anello, F. R. (2018), "Nowhere to Turn: The Protection Needs of Children Defecting from Criminal Gangs" in M. Crock and L. Benson (eds.), Protecting Migrant Children: In Search of Best Practice (439-459), Cheltenham: Edwards Elgar Publishing.

Archambault, J. (2010), "The Status Shift of Refugee Children in Settlement: An Analysis of the Norwegian Context", The International Journal of Children's Rights, 18(3), $437-456$.

Arnold, S. (2018a), Children's Rights and Refugee Law: Conceptualising Children within the Refugee Convention, Abingdon: Routledge.

Arnold, S. (2018b), "Child refugee and subsidiary protection appeals in Ireland", Child and Family Law Quarterly, 30(4), 350-371.

Arnold, S., Goeman, M. and Fournier, K. (2014), "The Role of the Guardian in Determining the Best Interests of the Separated CHild Seeking Asylum in Europe: A Comparative Analysis of Systems of Guardianship in Belgium, Ireland and the Netherlands", European Journal of Migration and Law, 16(4), 467-504.

Atkins, S. (2015), "Poverty, Race and Vulnerability: Effects on Children Growing Up in the Irish Asylum System", The International Journal of Children's Rights, 23(2), $425-476$.

Bailleul, C. (2018), "Coping strategies of unaccompanied minors lacking protection within the French context. The key role of political and civil society mobilisation" in M. Sedmak, B. Sauer and B. Gornik (eds.), Unaccompanied Children in European 
Migration and Asylum Practices. In Whose Best Interests? (134-154), Oxon, New York: Routledge.

Baker, T. and Bones, K. (2018), "Children and Refugee Law in Australia and the United States" in M. Crock and L. Benson (eds.), Protecting Migrant Children: In Search of Best Practice (274-298), Cheltenham: Edwards Elgar Publishing.

Beltman, D., Kalverboer, M., Zijlstra, E., van Os, C. and Zevulun, D. (2016), “The Legal Effect of Best-Interests-of-the-Child Reports in Judicial Migration Proceedings: A Qualitative Analysis of Five Cases" in T. Liefaard and J. Sloth-Nielsen (eds.), The United Nations Convention on the Rights of the Child: Taking Stock after 25 Years and Looking Ahead (655-680), Leiden and Boston: Brill Nijhoff.

Benson, L. and Thomas, C. R. (2018), "Procedure Deficits in Protection for Immigrant Children in the US" in M. Crock and L. Benson (eds.), Protecting Migrant Children:In Search of Best Practice (334-355), Cheltenham: Edwards Elgar Publishing.

Bhabha, J. (2001), "Minors or Aliens? Inconsistent State Intervention and Separated Child Asylum-Seekers", European Journal of Migration and Law, 3(3-4), 283-314.

Bhabha, J. (2009), Arendt's Children: Do today's Migrant Children Have a Right to Rights? Human Rights Quarterly, 31, 410-451.

Bhabha, J. (2014), Child Migration and Human Rights in a Global Age, Oxford: Princeton University Press.

Bhabha, J. and Young, W. (1999), "Not Adults in Miniature: Unaccompanied Child Asylum Seekers and the New U.S. Guidelines", International Journal of Refugee Law, n1(1), 84-125.

Bhabha, J., Crock, M., Finch, N. and Schmidt, S. (2007), Seeking Asylum Alone: A Comparative Study-Unaccompanied and Separated Children and Refugee Protection in Australia, the UK and the US, Annandale: The Federation Press.

Bolton, S. (2012), "Promoting the Best Interests of the Child in UK Asylum Law and Procedures", Journal of Immigration Asylum and Nationality Law, 26(3), 232-254.

Breen, C. (2003), "Refugee Law in Ireland: Disregarding the Rights of the Child-Citizen, Discriminating against the Rights of the Child", International Journal of Refugee Law, 15(4) 750-785.

Candappa, M. (200o), "The right to education and an adequate standard of living: Refugee children in the UK", The International Journal of Children's Rights, 8(3), 261-270.

Ceriani Cernadas, P. (2015), "The human rights of children in the context of international migration in W. Vandenhole, E. Desmet, D. Reynaert and S. Lembrechts (eds.), Routledge International Handbook of Children's Rights Studies (331-356), Oxon: Routledge.

Chase, E. (2019), "Transitions, Capabilities and Well Being: How Afghan Unaccompanied Young People Experience Becoming 'Adult' in the UK and Beyond”, Journal of Ethnic and Migration Studies, published online 19 March 2019. 
Chen, J., Desmet, E. and De Feyter, K. (2016), The Right to Education of Rural-urban Migrant Households in Chongqing, China (Localising Human Rights Working Paper Series no. 3), Antwerp: University of Antwerp.

Cohn, I. (1991), "The Convention on the Rights of the Child: What it means for Children in War", International Journal of Refugee Law, 3(1), 100-111.

Copeland, A. (2016), “Children's Rights and Australian Migration Law: Are they Mutually Exclusive?" in T. Liefaard and J. Sloth-Nielsen, The United Nations Convention on the Rights of the Child: Taking Stock after 25 Years and Looking Ahead (341-360), Leiden and Boston, Brill Nijhoff.

Connolly, H. (2015), "Seeing the Relationship between the UNCRC and the Asylum System through the Eyes of Unaccompanied Asylum Seeking Children and Young People", The International Journal of Children's Rights, 23(1), 52-77.

Crawley, H. (2006), Child first, Migrant Second: Ensuring that Every Child Matters, London: Immigration Law Practitioners' Association.

Crock, M. E. (2008), "Re-thinking the Paradigms of Protection: Children as Convention Refugees in Australia” in J. McAdam, Forced Migration, Human Rights and Security (155-180), Oxford and Portland: Hart Publishing.

Crock, M. E. (2013), "Of Relative Rights and Putative Children: Rethinking the Critical Framework for the Protection of Refugee Children and Youth", Australian International Law Journal, 20, 33-53.

Crock, M. E. (2015), "Justice for the Migrant Child: The Protective Force of the Convention on the Rights of the Child" in S. Mahmoudi, Child-Friendly Justice: A Quarter of a Century of the UN Convention on the Rights of the Child (221-241), Leiden: Brill Nijhoff.

Crock, M. E. and Bhabha, J. (2006), Seeking Asylum Alone-Australia: A study of Australian Law, Policy and Practice Regarding Unaccompanied and Separated Children, Annandale, Nsw: Themis Press.

Crock, M. and Benson, L. B. (eds.) (2018), Protecting Migrant Children. In Search of Best Practice, Cheltenham, UK: Edward Elgar Publishing.

Crock M. and Yale, P. (2018), "Children and the Convention Relating to the Status of Refugees" in M. Crock and L. Benson (eds.), Protecting Migrant Children: in Search of Best Practice (97-113), Cheltenham, UK: Edward Elgar Publishing.

de Clerck, H. M.-L., Ryngaert, J., de Wiart, E. C., Verhoeven, M., Vandenhole, W., Mahieu, P. and Timmerman, C. (2011), "Undocumented children and the right to education: illusory right or empowering lever? ", The International Journal of Children's Rights, $19(4), 613-639$.

Danisi, C. and Crock, M. (2018), "Immigration Control and the best interests of the Child in Europe" in M. Crock and L. Benson (eds.), Protecting Migrant Children: in Search of Best Practice (136-162), Cheltenham: Edwards Elgar Publishing.

Desmet, E. (2018), "Rural-urban Migration And Education In China: Unraveling Responses to Injurious Experiences" in T. Destrooper and S. E. Merry (eds.), Human 
Rights Transformation in an Unequal World (183-207). Philadelphia: University of Pennsylvania Press.

Desmet, E., Lembrechts, S., Reynaert, D. and Vandenhole, W. (2015), "Conclusions: Towards a field of critical children's rights studies" in W. Vandenhole, E. Desmet, D. Reynaert and S. Lembrechts (eds.), Routledge International Handbook of Children's Rights Studies (412-429). Oxon: Routledge.

Dotteridge, M. and Bhabha, J. (2017), Children's Rights in the Global Compacts: Recommendations for protecting, promoting and implementing the human rights of children on the move in the proposed Global Compacts, Initiative for Child Rights in the Global Compacts.

Drywood, E. (2010), "Challenging concepts of the 'Child' in Asylum and Immigration Law: the example of the EU", Journal of Social Welfare and Family Law, 32(3), 309-323.

Drywood, E. (2011), “'Child-Proofing' EU Law and Policy: Interrogating the Law-making Processes behind European Asylum and Immigration Provision”, International Journal of Children's Rights, 19(3), 405-428.

Dursun, A. and Sauer, B. (2018), "Asylum experiences in Austria from the perspective of unaccompanied minors. Best interests of the child in reception procedures and everyday life" in M. Sedmak, B. Sauer and B. Gornik (eds.), Unaccompanied Children in European Migration and Asylum Practices. In Whose Best Interests? (86-109). Oxon, New York: Routledge.

Engel, M. H., Phillips, N. K. and Della Cava, F. A. (2018), "Forced Migration and Immigration Programs for Children: The Emergence of a Social Movement", The International Journal of Children's Rights, 26(3), 468-488.

Evans, R. (2013), "Towards a creative synthesis of participant observation and participatory research: Reflections on doing research with and on young Bhutanese refugees in Nepal", Childhood, 2o(2), 169-184.

Evenhuis, M. (2013), “Child-Proofing Asylum: Separated Children and Refugee Decision Making in Australia”, International Journal of Refugee Law, 25(3), 535-573.

Farmer, A. (2011), "A Commentary on the Committee of Rights of the Child's Definition of Non-Refoulement for Children: Broad Protection for Fundamental Rights", Fordham Law Review Res Gestae, 8o, 39-48.

Farmer, A. (2018), "Finding a new balance: Bringing together children's rights law and migration policy for effective advocacy for migrant children" in J. Bhabha, J. Kanics and D. Senovilla Hernández (eds.), Research handbook on child migration (173-186). Cheltenham: Edward Elgar Publishing.

Feijen, L. (2009), "The Challenges of Ensuring Protection to Unaccompanied and Separated Children in Composite Flows in Europe", Refugee Survey Quarterly, 27(4), $63-73$.

Feller, E., Turk, V. and Nicolson, F. (2005), Refugee Protection in International Law: UNHCR's Global Consultations on International Protection, Cambridge University Press. 
Ferenci, B. (2000), Separated Refugee Children in Austria, International Journal of Refugee Law, 12(4), 525-547.

Frydman, L. and Bookey, B. (2018), "Applying the refugee definition to child-specific forms of persecution” in J. Bhabha, J. Kanics and D. Senovilla Hernández (eds.), Research handbook on child migration (187-207), Cheltenham: Edward Elgar Publishing.

Ghezelbash, D. (2018), "The Rise and Rise of Mandatory Immigration Detention" in M. Crock and L. Benson (eds.), Protecting Migrant Children: In Search of Best Practice (420-436), Cheltenham: Edwards Elgar Publishing.

Giannopoulou, C. and Gill, N. (2019), "Asylum Procedures in Greece: The Case of Unaccompanied Asylum Seeking Minors" in N. Gill and A. Good (eds.), Asylum Determination in Europe. Ethnographic Perspectives (109-130), Palgrave Macmillan.

Goldberg, P. (2018), "In search of solutions for unaccompanied children fleeing Central America" in M. Crock and L. B. Benson (eds.), Protecting Migrant Children. In Search of Best Practice (479-502), Cheltenham, UK; Northampton, MA, usa: Edward Elgar Publishing.

Goodwin-Gill, G. S. (1995). Unaccompanied Refugee Minors: The Role and Place of International Law in the Pursuit of Durable Solutions. The International Journal of Children's Rights, 3(3-4), 405-416.

Goodwin-Gill, G. S. (2012), "Introduction to the Expert Roundtable on The United Nations Convention of the Rights of the Child and its application to child refugee status determination and asylum processes", Journal of Immigration, Asylum and Nationality Law, 26(3), 226-231.

Gornik, B. (2018), "At the crossroads of power relations: the Convention on the Rights of the Child and unaccompanied minor migrants" in M. Sedmak, B. Sauer and B. Gornik (eds.), Unaccompanied Children in European Migration and Asylum Practices. In Whose Best Interests? (16-36). Oxon, New York: Routledge.

Grover, S. (2006), "Denying the Right of Trafficked Minors to be Classed as Convention Refugees: The Canadian Case Example ", The International Journal of Children's Rights, 14(3), 235-249.

Halvorsen, K. (2005), "Alone and Far from Home: Are Separated Refugee Children Adequately Protected?", Human Rights Review, 7, 77-91.

Hanson, K. and Nieuwenhuys, O. (eds.) (2013), Reconceptualizing Children's Rights in International Development: Living Rights, Social Justice, Translations, Cambridge: Cambridge University Press.

Hedlund, D. and Salmonsson, L. (2018), "Challenges in the Guardianship of Unaccompanied Minors Seeking Asylum”, The International Journal of Children's Rights, 26(3), 489-509.

Hedlund, D. and Wimark, T. (2019), "Unaccompanied Children claiming Asylum on the basis of Sexual Orientation and Gender Identity", Journal of Refugee Studies, 32(2), $257-277$. 
Holguin, C. and Kapur, K. (2018), "Defending Migrant Children and Youth in the InterAmerican system" in M. Crock and L. Benson (eds.), Protecting Migrant Children: In Search of Best Practice (189-200). Cheltenham: Edwards Elgar Publishing.

Hunter, A. (2001), "Between the Domestic and the International: The Role of the European Union in Providing Protection for Unaccompanied Refugee Children in the United Kingdom", European Journal of Migration and Law, 3(3-4), 383-410.

Inter-American Court of Human Rights, Advisory Opinion OC-21/4 of 19 August 2014, requested by the Argentine Republic, the Federative Republic of Brazil, the Republic of Paraguay and the Oriental Republic of Uruguay. Rights and guarantees of children in the context of migration and/or in need of international protection.

Jarvis, C. and Bolton, S. (2018), "Protecting Migrant Children in the UK" in M. Crock and L. Benson (eds.), Protecting Migrant Children: In Search of Best Practice (239-258), Cheltenham: Edwards Elgar Publishing.

Jastram, K. and Newland, K. (2005), "Family Unity and Refugee Protection" in E. Feller, Turk, N. V and F. (eds.), Refugee Protection in International Law: UNHCR's Global Consultations on International Protection (555-610), Cambridge: Cambridge University Press.

Josefsson, J. (2017), “Children's Rights to Asylum in the Swedish Migration Court of Appeal", International Journal of Children's Rights, 25(1), 85-113.

Kaime, T. (2004), "From Lofty Jargon to Durable Solutions: Unaccompanied Refugee Children and the African Charter on the Rights and Welfare of the Child", International Journal of Refugee Law, 16(3), 336-348.

Kalverboer, M., Beltman, D., van Os, C. and Zijlstra, E. (2017), "The Best Interests of the Child in Cases of Migration: Assessing and Determining the Best Interests of the Child in Migration", The International Journal of Children's Rights, 25(1), 114-139.

Kanics, J. (2018), "The best interests of unaccompanied and separated children. A normative framework based on the Convention on the Rights of the Child" in M. Sedmak, B. Sauer and B. Gornik (eds.), Unaccompanied Children in European Migration and Asylum Practices. In Whose Best Interests? (37-58), Oxon, New York: Routledge.

Kaukko, M. (2017), "The CRC of Unaccompanied Asylum Seekers in Finland", The International Journal of Children's Rights, 25(1), 140-164.

Kenny, M. A. and Loughry M. (2018), “'These don't look like children to me': Age Assessment of Unaccompanied and Separated Children" in M. Crock and L. Benson (eds.), Protecting Migrant Children: In Search of Best Practice (321-333), Cheltenham: Edwards Elgar Publishing.

Klaassen, M. and Rodrigues, P. (2017), "The Best Interests of the Child in EU Family Reunification Law: A Pleas for More guidance on the Role of Article 24(2) Charter", European Journal of Migration and Law, 19(2), 191-218.

Langrognet, F. (2018), "The Best Interests of the Child in French Deportation Case Law", Human Rights Law Review, $18(3), 567-592$. 
Lelliott, J. (2017), “Smuggled and Trafficked Unaccompanied Minors: Towards a Coherent, Protection-Based Approach in International Law", International Journal of Refugee Law, 29(2), 238-269.

Liden, H. and Rusten, H. (2007), "Asylum, Participation and the Best Interests of the Child: New Lessons from Norway", Children and Society, 21, 273-283.

Lundberg, A. (2011), "The Best Interests of the Child Principle in Swedish Asylum Cases: The Marginalization of Children's Rights", Journal of Human Rights Practice, 3(1), 49-70.

Lundberg, A. and Dahlquist, L. (2012), "Unaccompanied Children Seeking Asylum in Sweden: Living Conditions from a Child-Centred Perspective”, Refugee Survey Quarterly, 31(2), 54-75.

Lundberg, A. and Lind, J. (2017), “Technologies of Displacement and Children's Right to Asylum in Sweden", Human Rights Review, 18(2), 189-208.

MacDonald, A. (2009), "Protection Responses to Unaccompanied and Separated Refugee Children in Mixed Migration Situations", Refugee Survey Quarterly, 27(4), 48-62.

Martin, F. and Curran, J. (2007), "Separated Children: A Comparison of the Treatment of Separated Child Refugees Entering Australia and Canada", International Journal of Refugee Law, 19(3), 440-470.

McAdam, J. (2006), "Seeking Asylum under the Convention on the Rights of the Child: A case for Complementary Protection", The International Journal of Children's Rights, 14(3), 251-274.

McCallin, M. (1991), "The Convention on the Rights of the Child as an Instrument to Address the Psychosocial Needs of Refugee Children", International Journal of Refugee Law, 3(1), 82-99.

McCallin, M. (1992), The Psychological Well-being of Refugee Children: Research, Practice and Policy Issues, Geneva: International Catholic Child Bureau.

Mullally, S. (2011), "Separated Children in Ireland: Responding to “Terrible Wrongs", International Journal Refugee Law, 23, 632-655.

Muntarbhorn, V. (2019), "The Global Compacts and the Dilemma of Children in Immigration Detention", International Journal of Refugee Law, 3o(4), 668-673.

Neuman, G. L. (2018), "Detention as a Last Resort: The Implications of the Human Rights Committee's General Comment No. 35” in M. Crock and L. Benson (eds.), Protecting Migrant Children: In Search of Best Practice (381-395), Cheltenham: Edwards Elgar Publishing.

Nunes, R. (2016), "Protection of Internally Displaced Children and the Guiding Principles of Internally Displaced Persons" in T. Liefaard and \& J. Sloth-Nielsen, The United Nations Convention on the Rights of the Child: Taking Stock after 25 Years and Looking Ahead (414-432), Leiden and Boston, Brill Nijhoff.

Nykänen, E. (2001), "Protecting Children? The European Convention on Human Rights and Child Asylum Seekers", European Journal of Migration and Law, 3(3-4), $315^{-345}$ 
O'Donnell, D. (1994), "Resettlement or Repatriation: Screened-out Vietnamese Child Asylum-Seekers and the Convention on the Rights of the Child", International Journal of Refugee Law, 6(3), 382-401.

Oluese, A., Petros, S. and Abuya, E. O. (2018), "Under Siege: Alternative Care for Urban Unaccompanied and Separated Refugee Children in Kenya" in M. Crock and L. Benson (eds.), Protecting Migrant Children: In Search of Best Practice (163-188). Cheltenham: Edwards Elgar Publishing.

Ottosson, L. and Lundberg, A. (2013), "People Out of Place? Advocates' Negotiations on Children's Participation in the Asylum Application Process in Sweden", International Journal of Law, Policy and the Family, 27(2), 266-287.

Pask, E. (1989), "Unaccompanied Refugee and Displaced Children: Jurisdiction, Decision-Making and Representation", International Journal of Refugee Law, 1(2), 199-219.

Pobjoy, J. M. (2013), "A Child Rights Framework for Assessing the Status of Refugee Children" in S. Juss and C. Harvey (eds.), Contemporary Issues in Refugee Law (91-137), Cheltenham: Edward Elgar Publishing.

Pobjoy, J. M. (2015), "The Best Interests of the Child as an Independent Source of International Protection", International and Comparative Law Quarterly, 64(2), 327-363.

Pobjoy, J. M. (2017), The Child in International Refugee Law, Cambridge: Cambridge University Press.

Pobjoy, J. M. (2019), "Article 22: The Rights of the Refugee Child" in J. Tobin (ed.), The UN Convention on the Rights of the Child: A Commentary (818-855). Oxford: Oxford University Press.

Prabhat, D., Singleton, A. and Eyles, R. (2019), "Age is Just a Number? Supporting Migrant Young People with Precarious Legal Status in the UK", The International Journal of Children's Rights, 27(2), 228-250.

Price-Cohen, C. (1991), "The United Nations Convention on the Rights of the Child: Implications for change in the Care and Protection of Refugee C hildren", International Journal of Refugee Law, 3(4), 675-691.

Quennerstedt, A. (2013), "Children's Rights Research Moving into the Future Challenges on the Way Forward”, International Journal of Children's Rights, 21(2), 233-247.

Ressler, E. (1993), "Considerations in the Evacuation of Children from the Former Yugoslavia”, The International Journal of Children's Rights, 1, 331-356.

Rozzi, E. (2018), “Unaccompanied Minors in Italy: Children or Aliens? ” in J. Bhabha, J. Kanics and D. Senovilla Hernández (eds.), Research handbook on child migration (pp. 241-259), Cheltenham: Edward Elgar Publishing.

Russell, S. (1999), “Unaccompanied Refugee Children in the United Kingdom”, International Journal of Refugee Law, n(1), 126-154.

Ryngaert, J. and Vandenhole, W. (2017), "Undocumented migration: integrating the children's rights concept of nuanced vulnerability in human rights law" in E. Brems, 
E. Desmet and W. Vandenhole (eds.), Children's rights law in the global human rights landscape: isolation, inspiration, integration? (210-231), London: Routledge.

Sadoway, G. (2001), "Canada's Treatment of Separated Refugee Children”, European Journal of Migration and Law, 3(3-4), 347-381.

Sadoway, G. (2018), "Protection Measures for unaccompanied child migrants in Canada" in M. Crock and L. Benson (eds.), Protecting Migrant Children: In Search of Best Practice (299-317), Cheltenham: Edwards Elgar Publishing.

Samuels, H. (1997), "Child victims of immigration law and policy: A study of the effect of Hong Kong immigration law on children and their families", The International Journal of Children's Rights, 5(1), 97-122.

Schloenhardt, A. and Lelliott, J. (2018), "Migrant Children and the UN Protocols against Smuggling of Migrants and Trafficking in Persons", in M. Crock and L. Benson (eds.), Protecting Migrant Children: in Search of Best Practice (116-135) Cheltenham: Edwards Elgar Publishing.

Schmahl, S. (2001), "Integration of foreign students in the German school system", The International Journal of Children's Rights, 9(4), 285-311.

Schoenholz, A. L. (2012), "Developing the Substantive Best Interests of Child Migrants: A Call for Action”, Valparasio University Law Review, 46(4), 991-1018.

Sedmak, M., Lenarčič, B., Medarić, Z. and Žakelj, T. (2018), “'Not our children'. Unaccompanied minor asylum seekers in Slovenia" in M. Sedmak, B. Sauer and B. Gornik (eds.), Unaccompanied Children in European Migration and Asylum Practices. In Whose Best Interests? (110-133), Oxon, New York: Routledge.

Sedmak, M., Sauer, B. and Gornik, B. (eds.) (2018), Unaccompanied Children in European Migration and Asylum Practices. In Whose Best Interests? Oxon, New York: Routledge.

Shamseldin, L. (2012), "Implementation of the United Nations Convention on the Rights of the Child 1989 in the Care and Protection of Unaccompanied Asylum Seeking Children: Findings from Empirical Research in England, Ireland and Sweden", The International Journal of Children's Rights, 2o(1), 90-121.

Smith, A. W. (2018), "'Hiding in Plain Sight': Daily Strategies and Fear Management among Undocumented Refugee Children in Sweden", Journal of Refugee Studies $31(4), 5^{88-604 . ~}$

Smyth, C. (2013), "Is the Right of the Child to Liberty Safeguarded in the Common European Asylum System?", European Journal of Migration and Law, 15(2), 111-136.

Smyth, C. (2014), European Asylum Law and the Rights of the Child. Abingdon: Routledge.

Smyth, C. (2015), "The Best Interests of the Child in the Expulsion and First-entry Jurisprudence of the European Court of Human Rights: How Principled is the Court's Use of the Principle?", European Journal of Migration and Law, 17(1), 70-103. 
Smyth, C. (2019), "Towards a Complete Prohibition on Immigration Detention of Children", Human Rights Law Review, 19(1), 1-36.

Spijkerboer, T. (2009), "Structural Instability: Strasbourg Case Law on Children's Family Reunion", European Journal of Migration and Law, 11(3), 271-293.

Stalford, H. (2012), Children and the European Union: Rights, Welfare and Accountability. Hart.

Stalford, H. (2018), "David and Goliath: Due Weight, the State and Determining Unaccompanied Children's Fate", Journal of Immigration, Asylum and Nationality, 32(3), 258-283.

Steinbock, D. (1996), "Unaccompanied Refugee Children in Host Country Foster Families", International Journal of Refugee Law, 8(1), 6-48.

Suleiman AlMakhamreh, S. and Hutchinson, A. J. (2018), "Unaccompanied and Separated Syrian Refugee Children: Case Study of a New Feature for Social Work Practice in Jordan”, Refugee Survey Quarterly, 37(3), 353-377.

Sullivan, M. J. (2014), "Conditional Residence for Unauthorised Immigrant Parents", The International Journal of Children's Rights, 22(4), 776-806.

Taylor, S. (2018), "Asylum-seeking Children and the Australian Protection Visa Process" in M. Crock and L. Benson (eds.), Protecting Migrant Children: In Search of Best Practice (356-378), Cheltenham: Edwards Elgar Publishing.

Thorburn Stern R. (2015), "Unaccompanied and Separated Asylum-seeking Minors: Implementing a Rights-based Approach in the Asylum Process" in S. Mahmoudi, Child-Friendly Justice: A Quarter of a Century of the UN Convention on the Rights of the Child (242-255). Leiden: Brill Nijhoff.

Thronson, D. B. (2018a), "The Legal Treatment of Immigrant Children in the United States" in M. Crock and L. Benson (eds.), Protecting Migrant Children: In Search of Best Practice (pp. 259-273), Cheltenham: Edwards Elgar Publishing.

Thronson, D. B. (2018b), "Children's rights and U.S. immigration law" in J. Bhabha, J. Kanics and D. Senovilla Hernández (eds.), Research handbook on child migration (157-172). Cheltenham: Edward Elgar Publishing.

Tolfree, D. (2004), "Child Protection and Participation in Refugee Emergencies", Refugee Studies Quarterly, 23(2), 89-96.

Triggs, G. (2018), “The Impact of Detention on the Health, Wellbeing and Development of Children: Findings from the Second National Inquiry into Children in Immigration Detention" in M. Crock and L. B. Benson (eds.), Protecting Migrant Children. In Search of Best Practice (396-419), Cheltenham, UK; Northampton, MA, usa: Edward Elgar Publishing.

Tyler, K. and Whitman, S. (2018), "Don't Look Behind You: Unaccompanied and Separated Children Who Have Participated in Armed Conflict in South Sudan" in M. Crock and L. Benson (eds.), Protecting Migrant Children: In Search of Best Practice (460-478), Cheltenham: Edwards Elgar Publishing. 
UN Committee on the Protection of the Rights of All Migrant Workers and Members of Their Families, and UN Committee on the Rights of the Child. (2017a). Joint General Comment No. 3 (2017) of the Committee on the Protection of the Rights of All Migrant Workers and Members of Their Families and No. 22 (2017) of the Committee on the Rights of the Child on the general principles regarding the human rights of children in the context of international migration. UN Doc. CMW/C/GC/3-CRC/C/ $\mathrm{GC} / 22$.

UN Committee on the Protection of the Rights of All Migrant Workers and Members of Their Families, and UN Committee on the Rights of the Child. (2017b). Joint General Comment No. 4 (2017) of the Committee on the Protection of the Rights of All Migrant Workers and Members of Their Families and No. 23 (2017) of the Committee on the Rights of the Child on State obligations regarding the human rights of children in the context of international migration in countries of origin, transit, destination and return. UN Doc. $\mathrm{CMW} / \mathrm{C} / \mathrm{GC} / 4$-CRC/C/GC/23.

UN Committee on the Rights of the Child, Report on the Day of General Discussion, The Rights of all Children in the Context of International Migration (2012).

UN Committee on the Rights of the Child (2005), General Comment No. 6 (2005), Treatment of unaccompanied and separated children outside their country of origin. UN Doc. CRC/GC/2005/6.

UN Committee on the Rights of the Child. (2014). General Comment No. 14 (2013), The right of the child to have his or her best interests taken as a primary consideration (art. 3, para. 1). UN Doc. CRC/C/GC/14.

UN General Assembly (2018a), Global Compact for Safe, Orderly and Regular Migration. UN Doc. A/73/L.66, Annex.

UN General Assembly (2018b), Global Compact on Refugees. UN Doc. A/73/12. UNHCr ExCom. (1987). Conclusion No. 47 (XxxviII) Refugee Children UN Doc. A/42/12/Add.1.

UNHCR. (1987), Note on Refugee Children, UN Doc. EC/scP/46, Geneva.

UNHCr. (1993), Policy on Refugee Children, UN Doc. EC/scP/82, Geneva.

UN HCR. (1994), Refugee Children: Guidelines on Protection and Care, Geneva.

UN HCR. (2002), Global Consultations on International Protection: Refugee Children. UN Doc. EC/GC/02/9.

UNHCR. (2008), Guidelines on Determining the Best Interests of the Child, Geneva.

UNHCR. (2009), Guidelines on International Protection: Child Asylum Claims under Article ${ }_{1} A(2)$ and ${ }_{1} F$ of the ${ }_{195}$ Convention and/or 1967 Protocol Relating to the Status of Refugees. UN Doc. HCR/GIP/og/o8.

UN HCR. (2018), Guidelines on Assessing and Determining the Best Interests of the Child, Geneva.

UNHCR AND UNICEF (2014), Safe and Sound: What States can do to Ensure Respect for the Best Interests of Unaccompanied and Separated Children in Europe, Geneva. 
UNICEF (2007), Promoting the Rights of Children With Disabilities, Innocenti Research Centre.

van Doore, K. E. (2018), "Child Migration and Trafficking in South East Asia" in M. Crock and L. Benson (eds.), Protecting Migrant Children: In Search of Best Practice (203-218). Cheltenham: Edwards Elgar Publishing.

Van Os, K., Zijlstra, E., Knorth, E. J., Post, W. and Kalverboer, M. (2018), "Methodology for the best interests of the child assessement for recently arrived unaccompanied refugee minors" in M. Sedmak, B. Sauer and B. Gornik (eds.), Unaccompanied Children in European Migration and Asylum Practices. In Whose Best Interests? Oxon, New York: Routledge.

van Walsum, S. (2002), "Comment on the Sen Case. How Wide is the Margin of Appreciation Regarding the Admission of Children for Purposes of Family Reunification? ECHR, December 21st 2001 (Sen v. the Netherlands), nr. 31465/96", European Journal of Migration and Law, 4(4), 511-520.

van Walsum, S. (2009), "Against All Odds: How Single and Divorced Migrant Mothers were Eventually able to Claim their Right to Respect for Family Life", European Journal of Migration and Law, n1(3), 295-311.

Vandenhole, W. and Ryngaert, J. (2013), "Mainstreaming children's rights in migration litigation: Muskhadzhiyeva and others v. Belgium" in E. Brems (ed.), Diversity and European Human Rights. Rewriting Judgments from the ECHR (68-92), Cambridge: Cambridge University Press.

Zschirnt, E. (2011), "Does migration status trump the best interests of the child? Unaccompanied minors in the EU asylum system", Journal of Immigration, Asylum and Nationality Law, 25(1), 34-55. 